\title{
Forestry School News
}

BRITISH COLUMBIA UBC Faculty of Forestry and Canadian Cancer Society join to find a permanent home for Camp Goodtimes

On December 15, 2003, the UBC Faculty of Forestry joined together with the Canadian Cancer Society BC and Yukon Division to celebrate the signing of a $\$ 1$ million agreement to establish a longterm home for Camp Goodtimes at UBC's Malcolm Knapp Research Forest near Maple Ridge.

Camp Goodtimes is a special summer camp run by the Canadian Cancer Society that enables kids with a history of cancer to get away from their medical treatment. The camp has been operating for nearly 20 years, but the camp has never had a permanent home - until now. The collaborative arrangement will see Camp Goodtimes occupy the Loon Lake facility for five weeks each summer to allow the children to enjoy camping, hiking, boating, swimming, and the wonderful forest surroundings.

Located approximately $60 \mathrm{~km}$ from downtown Vancouver, the UBC Malcolm Knapp Research Forest was established by a Crown Grant to UBC in 1949 as a facility for research, demonstration and education in the field of forestry sciences. The 5000-hectare research forest has a thriving research community, which includes researchers and students from several UBC faculties, the provincial and federal governments, and other universities in Canada and internationally. Since its establishment, over 750 research projects have been initiated at the Research Forest. Many of the projects are long term, spanning close to 50 years and including some of the most extensive datasets in western North America.

The Loon Lake Research and Education Centre is an integral part of the research forest activities. Originally built in 1948-9 to house the UBC Faculty of Forestry field camps, the camp continues to be used for this purpose every spring. Today, many other educational groups take advantage of this setting for their outdoor needs. In addition, a wide range of adult and youth groups rent the facility year round for retreats, workshops and other events.

The \$1 million contribution from the Canadian Cancer Society will have a significant impact on the Faculty's plans for the renewal of the Loon Lake facility, a major priority for the Faculty of Forestry. Many of the buildings at Loon Lake were constructed over fifty years ago, and are well beyond their original planned life. The redevelopment of Loon Lake is essential if it is to continue to provide students, community members, and researchers with the unique educational opportunity that the research forest provides. The funds from the society will go towards building an amphitheatre, improved access and lighting, and new accommodation facilities.

The first campers will arrive at the new site this summer to mark the 20th Anniversary of Camp Goodtimes. Canadian Cancer Society BC and Yukon Division CEO Barbara Kaminsky expressed her excitement during the celebration "we'd been looking for a longterm camp site for quite some time and we're thrilled about our new partnership with UBC. Loon Lake is a gift to all the children of BC and the Yukon who

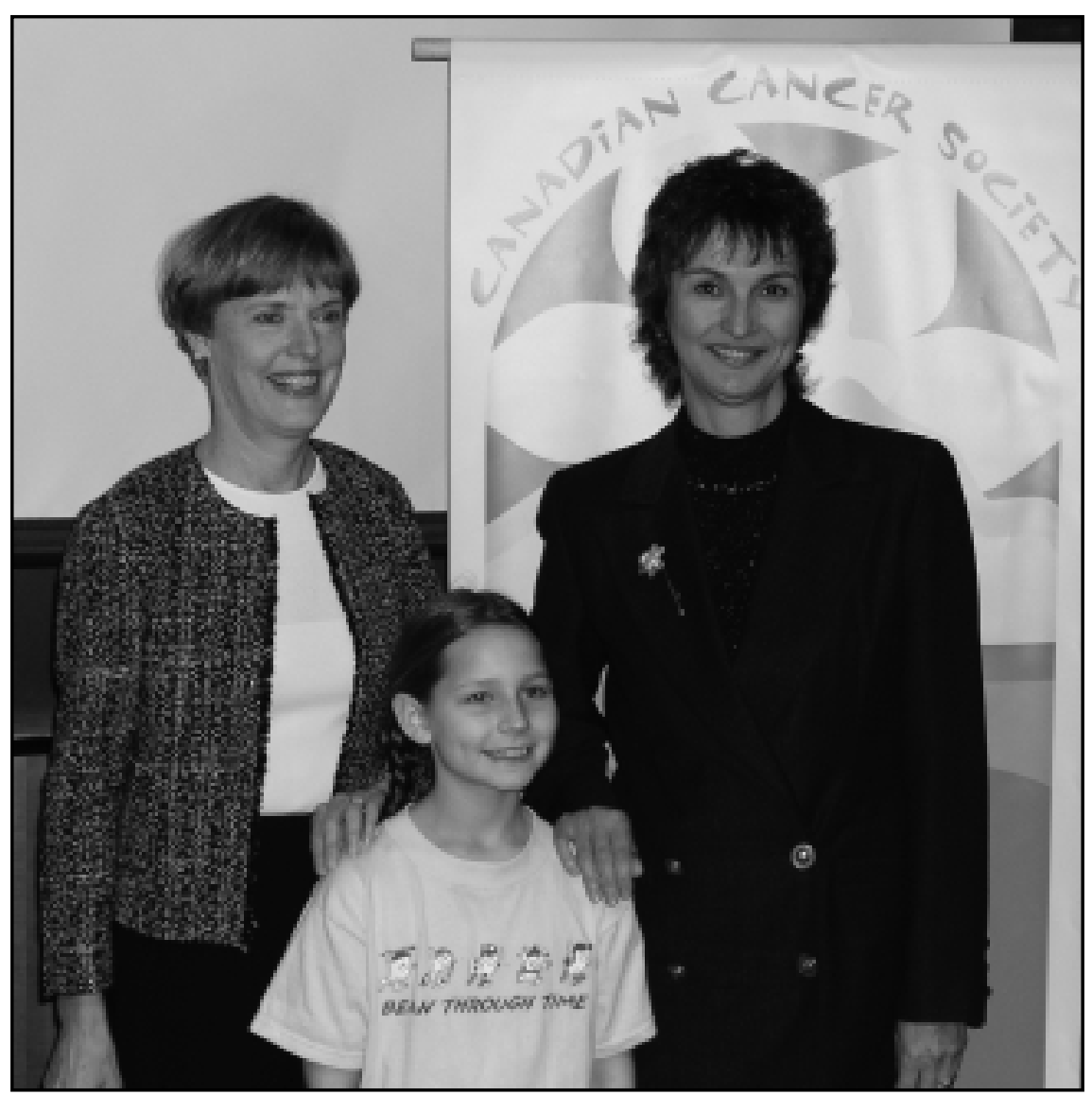

UBC President Martha Piper, 9-year-old cancer survivor Victoria Fawkes, and Barbara Kaminsky. have a history of cancer."

UBC president Martha Piper responded "The Malcolm Knapp Research Forcial learning experience for over 50 years. We are delighted to be able to share this resource with the communities we serve, and we're very pleased that it will contribute to the well-being of children living with cancer."

UBC Research Forest manager Paul Lawson said the partnership will raise the profile of the centre and that it represents a step forward in recognizing that forestry is a social institution - as well as an economic and environmental asset.

If you would like to find out more about the UBC Malcolm Knapp Research Forest and Faculty of Forestry's plans for redevelopment at Loon Lake, please contact Katrina Evans, Senior Development Officer, UBC Faculty of Forestry, phone: 604822 8716, email: katrina.evans@ ubc.ca or go to www.loonlakecamp.com est has been providing UBC students a spe- 


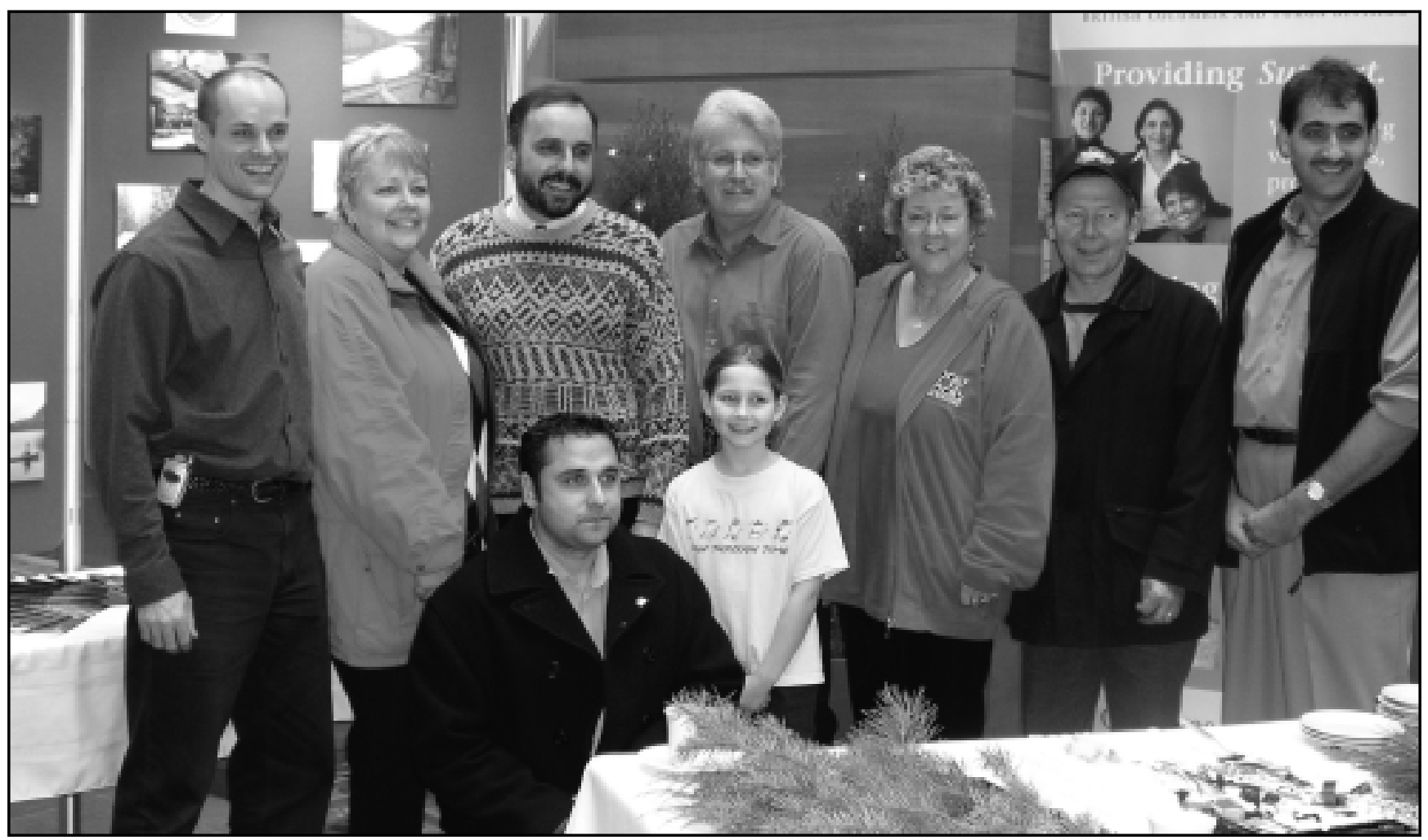

Manager of UBC Research Forest, Paul Lawson (3rd from left), 9-year-old cancer survivor Victoria Fawkes (Centre) with Malcolm Knapp Research Forest Staff.

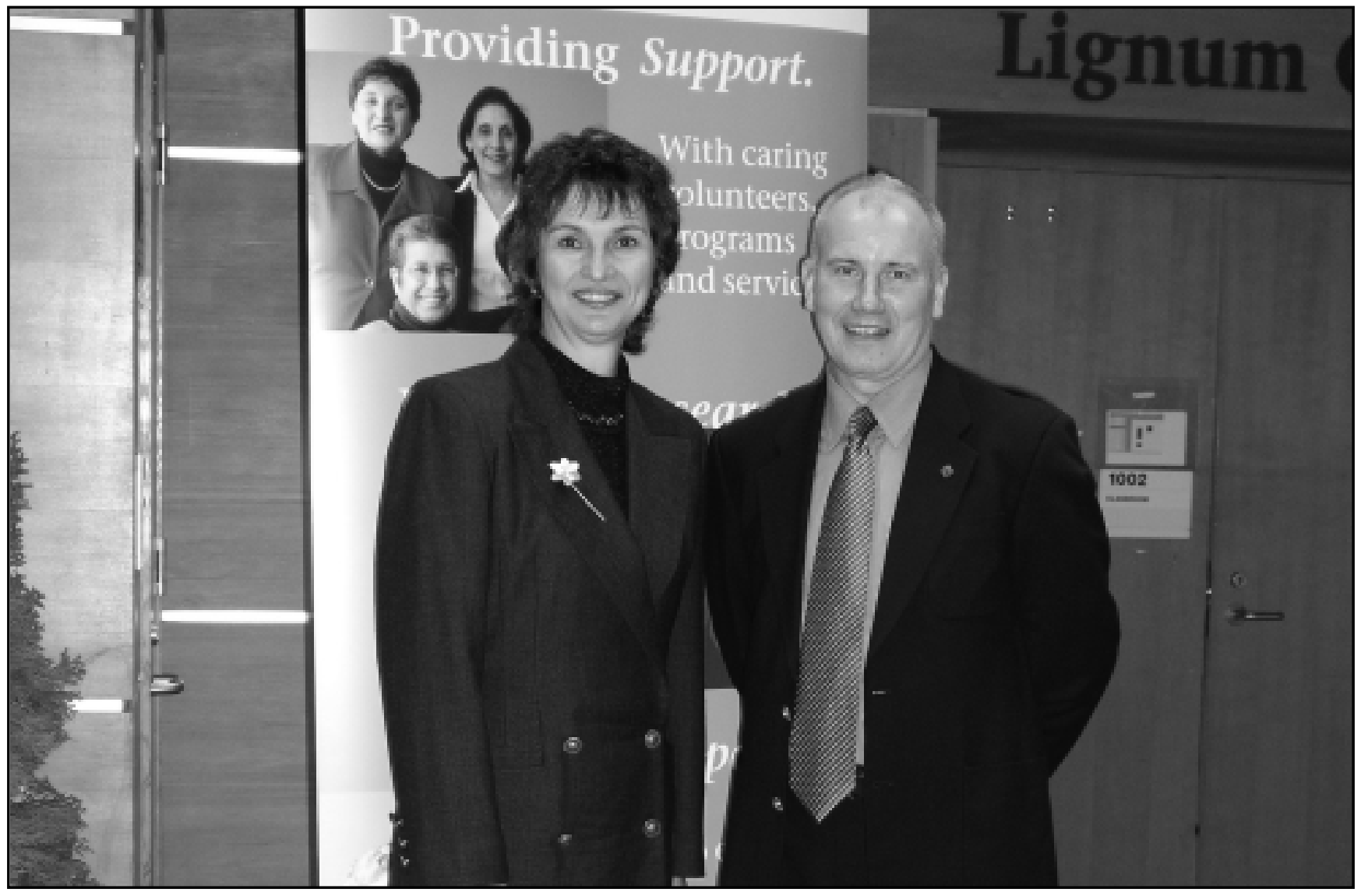

UBC Faculty of Forestry Dean Jack Saddler and Canadian Cancer BC and Yukon Division CEO Barbara Kaminsky. 